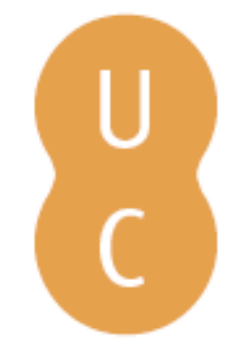

\title{
pommalina
}

\section{Medea, Clytemnestra and Antigone: a psychological approach according to the tragedies and the myths under the frame of the patriarchal society}

\section{Autor(es): $\quad$ Vrachiotis, Petros}

Publicado por: Centro de Estudos Clássicos e Humanísticos; Imprensa da Universidade de Coimbra

\author{
URL \\ persistente: URI:http://hdl.handle.net/10316.2/31592 \\ DOI: $\quad$ DOI:http://dx.doi.org/10.14195/978-989-8281-41-8_1
}

Accessed : $\quad$ 26-Apr-2023 05:05:45

A navegação consulta e descarregamento dos títulos inseridos nas Bibliotecas Digitais UC Digitalis, UC Pombalina e UC Impactum, pressupõem a aceitação plena e sem reservas dos Termos e Condições de Uso destas Bibliotecas Digitais, disponíveis em https://digitalis.uc.pt/pt-pt/termos.

Conforme exposto nos referidos Termos e Condições de Uso, o descarregamento de títulos de acesso restrito requer uma licença válida de autorização devendo o utilizador aceder ao(s) documento(s) a partir de um endereço de IP da instituição detentora da supramencionada licença.

Ao utilizador é apenas permitido o descarregamento para uso pessoal, pelo que o emprego do(s) título(s) descarregado(s) para outro fim, designadamente comercial, carece de autorização do respetivo autor ou editor da obra.

Na medida em que todas as obras da UC Digitalis se encontram protegidas pelo Código do Direito de Autor e Direitos Conexos e demais legislação aplicável, toda a cópia, parcial ou total, deste documento, nos casos em que é legalmente admitida, deverá conter ou fazer-se acompanhar por este aviso.

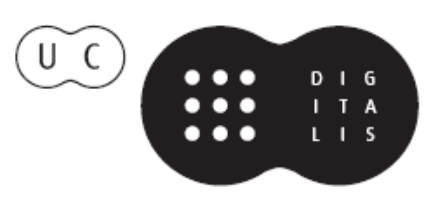


COLECÇÃo AUTORES GREgOS E LATINOS Sérte ENSATOS

\section{Maria de Fátima Silva Susana Hora Marques (eds.)}

\section{Tragic Heroines} ON ANCIENT

\section{AND Modern STAGE}




\section{Medea, Clytemnestra and Antigone: A PSYCHOLOGICAL APPROACH ACCORDING TO THE \\ TRAGEDIES AND THE MYTHS UNDER THE FRAME OF THE PATRIARCHAL SOCIETY}

Petros Vrachiotis (University of Athens)

Greek tragedy is dominated by imposing female figures, heroines who have become symbols and admirable archetypes in every civilization through the centuries. Passionate women, blessed with natural beauty, wisdom, intelligence and courage, who dared to go beyond the narrow frame of their time, oppose the laws and their rulers and turn the social establishment upside down. There is no place for tragic heroines, in a patriarchal society. Their acts needed to be devalued and these women had to be presented as crazy witches, prostitutes, or murderesses of their relatives. Nevertheless these female figures always stood before these imputations like large stones. In order to marginalize women, the newly established man-dominated society tried to suspend these figures and replace them with softer ones, such as Penelope (faith and obedience), Antigone (duty), Alcestis (sacrifice and modesty) and Ariadne (abandonment). But even these new examples were beyond the usual ones and looked alike the older ones, which could not be tamed.

Medea turns the divine Order of things upside down using her tremendous knowledge: not only she 
possesses the secrets of immortality, but she can beat death and give youth back to an elder. According to Euripides she is quite aware of her fate:

...If you offer fools some brand new wisdom, they'l consider you quite useless, not someone wise.]

And if, within the city, people think of you as greater than those men who seem quite wise, you'll appear a nuisance. So it is with me. For I'm a knowledgeable woman. I make some people envious ${ }^{1}$.

Medea's name is not occasional. It derives from the verb $\mu$ '́ $\delta$ o $\mu \alpha$ which means 'I think, I discover, I foresee'. Her misfortunes commenced right after her wedding. Helping Jason to beat monsters and become a king, this femina universalis connected her name with the forbidden knowledge and the unexplored female soul. Men demanded women to be illiterate and silent. After the downfall of matriarchy, they established 'menonly' democracies and banished any knowledge they could not control. Thus, Medea has to be banished as an 'undesirable good'.

Euripides describes Medea as a crazy, jealous and mean woman. According to the myth, she is the ruler of life who can resurrect and revive people. But since only Zeus can resurrect Dionysus, Medea is forbidden to do so. We will never know if this 'witch' resurrected her

${ }^{1}$ Johnston, I. 2008: vv. 298-304. 
children, because the Knowledge is buried and Medea is banished as an annoying alchemist.

Medea has turned the male world upside down: she betrayed her father, killed her brother and fell in love with Jason because she chose to do so. She is the untamed female nature carrying chaos, success, action and death within her. She has overwhelmed the pseudo-conventions and the laws of her time. Must she be punished, there and forth? Under what penalty? Euripides remains silent. Gods themselves stand powerless in front of her. Not only she is not punished, but she marries the great king of Athens, Aegeas, and provides with him a male heir, Medos.

Medea is referred to as a goddess in a forgotten Mycenaean slate. She was worshiped in Corinth until the Historic Ages. Ancient craters depict her as a priestess in Eleusis - as well as in Rome - or place her among the heroes in the Elysian Fields. The Greeks of South Italy honored her with hymns. Even Apollonius of Rhodes praised her as a "treasure" that saved the Argonauts, equal to Jason. But the annoying character of Medea is synonymous to horror until today. Our 'christianic' world is convicted to worship the safe model of a mother-virgin who has sacrificed her eroticism for the common good. The horrible Medea is interpreted as a half-lunatic jealous woman. Nevertheless, her impunity is not justified. Whoever tried to simplify Medea has failed.

Clytemnestra is a dreadful woman with a strange beauty. Agamemnon had to murder his own first cousin 
Tantalus in order to have her. With this marriage he became a powerful ruler as he entered the mighty dynasty of Heracleidae, which counted 1.700 years of royal history and thanks to the powerful name of the dynasty, Agamemnon was appointed commander general of the Greek army against the Trojans.

But Clytemnestra is born to be a queen. After her husband's departure she takes over the kingdom and she reflects the female model of ruler: she exercises her rights and flirts freely with Aegisthus, as Agamemnon does with his bondmaids. When he returns victorious from Troy, Clytemnestra is worthy holding the double axe, the symbol of kingship. Neither she will hand it back, nor tolerate the presence of young Cassandra, Agamemnon's trophy from the war. She decides to kill Agamemnon - not with some poison - but with a weapon. She comes face to face with the tough general, while Aegisthus only strikes when the king has already passed away, just to claim his throne.

Clytemnestra will neither repent, nor consider her deed to be a crime. Speaking to her daughter Electra, she will define this murder as a mother's revenge in the name of Iphigenia. Clytemnestra is all about womanpower. No one could have her as a trophy. The men of her time were deeply attracted to her. The tragedians were messed up by her. And even today, we are struck with awe when we refer to her. As a heroine she absorbs the dramatis personae in Agamemnon. She rules over the stage invincible, cruel and independent. She has no place in the patriarchal society, where women have to conform according to rules set by men. 
Clytemnestra is presented as an ordinary woman only in Electra by Euripides. She runs towards her persecuted daughter when she finds out that she has a grand child. The great queen is now running after a baby like an ordinary grandmother. In such a society, Clytemnestra can only be punished as a mother. In this kind of society, a woman can only be tolerated as a mother. Electra can hate her mother as much as she wants, but she is forbidden to hate her father who has a pregnant mistress of her age. The tragedians will not allow Agamemnon to apologize, unlike Clytemnestra, who is guilty and has to pay with her own life.

But the queen of Argos has also another aspect: the tragic matricide she is representing is probably re-echoing our own malevolent side. Perhaps it is addressed to us as a hidden thought which cannot be discussed and so it has to be buried in the strange and dark undergrounds of our subconscious. Clytemnestra is - at the same time - "beloved" as well as "hated", as crushed Electra says while mourning her.

Antigone is the big and unpleasant surprise for Sigmund Freud, as she uncovers the deception of the so-called 'Oedipus Complex'2. For neither she, nor her brothers and sister, are children of an incestuous marriage. In Odyssey 11.271-281, Oedipus meets his mother Epicasta (not Jocasta!) and there is no mention of his ignorance or self-blinding. According to Pausanias, these verses are evidence that Oedipus had no children by his mother:

${ }^{2}$ Eleftheriou, A. 2005: 18908-18916. 
For how could the report of his wickedness be immediately abolished, if he had four children by Jocasta? These children indeed were the offspring of Euryganea the daughter of Hyperpas: and this is evinced by the author of the verses called Oedipodia. Onasias painted for the Plateenses Euryganea, with a sorrowful countenance, on account of the battle between her sons.

Crucial information is also given by Pherecydes from Syros ( $4^{\text {th }}$ century b.C). Oedipus neither took his eyes out, nor left Thebes. He married a third wife, Astymedusa, daughter of Sthenelus, and lived out his life as a great and respected leader (Pherecydes F95 in Jacoby $F G r H$ ). Of course the tragic poets and the audience had read Homer and must had been aware of the myth. Still Oedipus is an incestuous person (husband to his mother/brother to his children). I guess because the plot needed to be more complicated, and thus more dramatic.

But let us return to Antigone. Oedipus' daughter is so bold that although she is afraid of death she is defying him, reminding us that sometimes we must defend what we have proclaimed.

Antigone has a disastrous effect on Creon's life. His son Haemon and his wife Eurydice will commit suicide on account of his persistence to punish her. Creon is known for ordering Antigone's execution, not because of any virtue. Finally he is disgraced and

${ }^{3}$ Taylor, T. 1824: 11. 
humiliated, because his conflict with the "unimportant" girl is the antithesis between Kratos, 'power', and the ideals of a noble soul.

Antigone is the exemplum of devotion and resistance. Creon is a leader expressing the law of the citystate but he refuses to bury a dead man. Which law is he appealing to? What is going on beyond his misogynism? Antigone is a sensitive girl with the unquestionable ethos and a thousand more virtues. At the very moment she stands in front of Creon, she is carrying on her delicate shoulders all the characteristics of the previous female figures: the chaos of Medea and the rough determination of Clytemnestra. Creon's nightmare is a power he cannot control or tame - a proud Doric column in the shape of a sweet girl. If he was to face Hercules, he would have appeared servile and magnanimous, but Antigone is an ant he has to crush.

Both Creon and Antigone stand for the Law. However, Creon holds the power. When Antigone is brought in front of him, he commands her to look at him, but she ignores him. She refuses to honor him with a single look, and Creon is the only one who can feel her actual and deepest contempt. Antigone regards him as the miasma of the city, a coward and a timid man. She will not look at him, not because she is afraid of him, but because she does not want to be contaminated by his disgusting presence. Antigone bares the halo of the Heroic Times. Creon realizes that if somebody could arm her, she would not hesitate to kill him - or anyone who would try to stop her from executing her duty. Her 
figure is too much for the patriarchal society, thus, she has to be abolished.

Antigone is addressing her last words towards the dead members of her family:

But I cherish good hope that my coming will be welcome to my father and pleasant to thee, my mother, and welcome, brother, to thee ${ }^{4}$.

At this point I believe it is crucial to recall Sophocles' version of Oedipus the King, as well as his Electra, although her example is not being discussed here. Based on these two tragedies, Sigmund Freud took the chance to lay down the 'Oedipus' and 'Electra Complex'. According to the last theory, Antigone's resistance lies not in her courage to do so, but also because she is "in love" with her father and her brother. The least we can say is that Freud is an ignorant, because even Sophocles knew that Antigone was a child of a lawful marriage, and not of an impious union. Nevertheless, the so called 'Father of Psychoanalysis' took the chance to devise this farce and forget his forefather Lot, Patriarch of the Jews, who had slept with both of his daughters and left them pregnant (Genesis 19. 31-35). Neither Oedipus was in love with his mother, nor did his daughters fall in love with him. On the contrary, Lot's daughters consciously had sex with their father, giving birth to incestuous children, as well as to moral and social questions.

${ }^{4}$ Jebb, R. C. 1904: vv. 897-899. 
Medea, Clytemnestra and Antigone are amongst the strongest tragic figures, but the list of the tragic heroines is a long one. All of them are strong, resistant and indiscipline in spite of their great afflictions. They have every characteristic of a female prince and they are stronger than men, as they are powerful personalities. In his Principe, Machiavelli praises these virtues as a constitutive element of the male power. But this is a forbidden area for females. The Christians will lock women up in their appartments and turn them into weak and pale mistresses, keeping knowledge away from them. Knowledge and power can become dreadful weapons in the hands of a woman. Only "drippy" Bush and Bin Laden have the right to threat the mankind! 


\section{Bibliography}

Baconicola-Ghéorgopoulou, C. (1994), "Filicide in Euripides", in Moments of Greek Tragedy. Athens: M. Kardamitsa Book Institute, 100-103.

Eleftheriou, A. (2005), “'Oedipus Complex’: a historical forgery. How did Freud distort Sophocles?", Davlos 282. Athens: 18908-18916.

Jebb, R. C. (1904), Sophocles. Antigone. Cambridge: Cambridge University Press.

Johnston, I. (2008), Euripides. Medea. Virginia.

Kalokyres, C. D. (1950), "The ethical philosophy of Sophocles", Elliniki Dimiourgia 5. 47. Athens: 99-111.

Retoula, A. (2008), "Rebel-women: Diachronic prototypes of the female soul”, Davlos 312. Athens: 21981-22002.

Taylor, T. (1824), Pausanias. The Description of Greece 3 - chap. 5. London.

Yahanatzis, Y. (2002), The religious misogynism: Woman in the "paradises" of monotheism. Rafina: Albouro Publications. 